\title{
Historicity of nursing graduate studies in Brazil: an analysis of the Sociology of the Professions
}

\author{
Historicidade da pós-graduação em enfermagem no Brasil: uma análise da sociologia das profissões
}

Historicidad de los estudios de posgrado en enfermería en Brasil: un análisis de la sociología de las profesiones

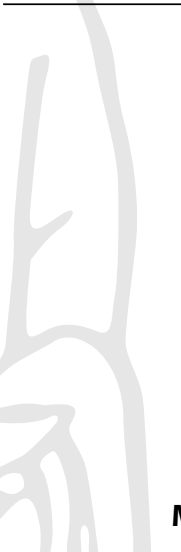

Fernanda Alves dos Santos Carregal' ORCID: 0000-0001-7777-1610

Biannka Melo dos Santos' ORCID: 0000-0002-4106-9261

Helena Pereira de Souza' ORCID: 0000-0001-6895-1820

Fernanda Batista Oliveira Santos' ORCID: 0000-0002-8523-0547

Maria Angélica de Almeida Peres" ORCID: 0000-0002-6430-3540

Maria Itayra Coelho de Souza Padilha"t ORCID: 0000-0001-9695-640X

'Universidade Federal de Minas Gerais. Belo Horizonte, Minas Gerais, Brazil.

"Universidade Federal do Rio de Janeiro. Rio de Janeiro, Rio de Janeiro, Brazil.

II' Universidade Federal de Santa Catarina. Florianópolis, Santa Catarina, Brazil.

How to cite this article:

Carregal FAS, Santos BM, Souza HP, Santos FBO, Peres MAA, Padilha MICS. Historicity of nursing graduate studies in Brazil: an analysis of the Sociology of the Professions. Rev Bras Enferm. 2021;74(6):e20190827. https://doi.org/10.1590/0034-7167-2019-0827

\section{Corresponding author:}

Fernanda Alves dos Santos Carregal E-mail: fernanda.carregal@hotmail.com

EDITOR IN CHIEF: Dulce Barbosa ASSOCIATE EDITOR: Maria Saraiva

Submission: 03-12-2020

Approval: 05-09-2021

\section{ABSTRACT}

Objectives: to analyze the scientific productions about the history of graduate studies in Brazilian nursing in the light of Eliot Freidson's Sociology of the Professions. Methods: an integrative review, carried out in the databases indexed in Virtual Health Library. The Preferred Reporting Items for Systematic Reviews and Meta-Analyses recommendations were followed. Thematic content analysis and Eliot Freidson's concepts were adopted. Results: two categories emerged: "Institutionalization of graduate courses in Brazilian nursing", highlighting the historical process of professionalization in nursing through transition from empirical to professional care, subsidized by the monopoly of the construction of one's own knowledge; "The scientific production of graduate nursing in Brazil", showing the strengthening of a new generation of nurse researchers, given the greater scientificity in teaching due to implementation of graduate studies. Final Considerations: the analyzes present the historicity of graduate studies'institutionalization, supporting the understanding of professionalization outlines of Brazilian nursing.

Descriptors: Nursing Graduate Education; Nursing History; Nursing; Review; Brazil.

\section{RESUMO}

Objetivos: analisar as produções científicas acerca da história da pós-graduação em enfermagem brasileira à luz da Sociologia das Profissões de Eliot Freidson. Métodos: revisão integrativa, realizada nas bases indexadas na Biblioteca Virtual da Saúde. Seguiram-se as recomendações da Preferred Reporting Items for Systematic Reviews and Meta-Analyses. Adotaram-se a Análise de Conteúdo Temática e as concepções de Eliot Freidson. Resultados: elencaram-se duas categorias: "Institucionalização da pós-graduação em enfermagem brasileira", ressaltando o processo histórico da profissionalização da enfermagem pela transição de um cuidado empírico para o profissional, subsidiado pelo monopólio da construção de saber próprio;"A produção científica da pós-graduação em enfermagem no Brasil", evidenciando o fortalecimento da nova geração de enfermeiros pesquisadores no país, visto a maior cientificidade no ensino pela implantação da pós-graduação. Considerações Finais: as análises apresentam a historicidade da institucionalização da pós-graduação subsidiando a compreensão dos delineamentos da profissionalização da enfermagem brasileira.

Descritores: Educação de Pós-Graduação em Enfermagem; História da Enfermagem; Enfermagem; Revisão; Brasil.

\section{RESUMEN}

Objetivos: analizar las producciones científicas sobre la historia de los estudios de posgrado en enfermería brasileña a la luz de la Sociología de las Profesiones de Eliot Freidson. Métodos: revisión integradora, realizada en las bases de datos indexadas en la Biblioteca Virtual en Salud, se siguieron las recomendaciones del Preferred Reporting Items for Systematic Reviews and Meta-Analyses. Se adoptaron el análisis de contenido temático y los conceptos de Eliot Freidson. Resultados: se enumeraron dos categorías: "Institucionalización de los posgrados en enfermería brasileña", destacando el proceso histórico de profesionalización de la enfermería a través de la transición del cuidado empírico al profesional, subsidiado por el monopolio de la construcción del conocimiento propio; "La producción científica de la enfermería graduada en Brasil", mostrando el fortalecimiento de la nueva generación de enfermeras investigadoras en el país, dada la mayor cientificidad en la docencia debido a la implementación de estudios de posgrado. Consideraciones Finales: los análisis muestran la historicidad de la institucionalización de los estudios de posgrado, apoyando la comprensión de los trazos de la profesionalización de la enfermería brasileña.

Descriptores: Educación de Posgrado en Enfermería; Historia de la Enfermería; Enfermería; Revisión; Brasil. 


\section{INTRODUCTION}

Nursing, before being recognized as a profession, showed signs of being more than a necessary occupation for patient care. Its power and importance for the maintenance of health institutions gave rise to the concern with the training and hierarchization of their personnel, which was initially conducted by physicians ${ }^{(1)}$.

Nursing's work, in a permanent condition, in hospitals, highlighted the division of tasks based on thinking and doing between physicians and nurses, such as when religious individuals did charity caring for the sick in their communities and in the Santas Casas de Misericórdia (Brotherhood places whose mission is to treat and support the sick and disabled, in addition to providing assistance to "exposed" - newborns abandoned in the institution), and also in recruiting people for wars. At that time, which precedes modern nursing, the knowledge needed for care was transmitted through practical training, without a theoretical framework to support them as nursing knowledge ${ }^{(1)}$.

Professional nursing or modern nursing was born in Victorian England, driven by the ideas of nurse Florence Nightingale, who, based on her care for soldiers wounded in the Crimean War (18531856), realized the need for institutionalization and schooling of nursing knowledge ${ }^{(2)}$.

From the consolidation of the School and the Nightingale model, this was taken to several countries, especially in the United States, Capitalist and Taylorist production characteristics were incorporated, in a shorter period of time and within the best efficiency. This movement to obtain the best care response made professionals seek greater strength in their knowledge ${ }^{(3)}$.

With the advent of medical hyperspecialization and the serious public health problems experienced in Brazil at the beginning of the $20^{\text {th }}$ century, the government made a commitment, in 1923 , to the North American nursing training model, based on the Nightingale model, formalizing the first school of nursing in Brazil considered to have a high standard of training, Escola de Enfermagem Anna Nery (EEAN). The creation of this School made it possible to train nurses from a perspective of education and career continuity in nursing, including from an academic point of view, with scholarships offered for specialization, master's and doctoral degrees abroad, with the main destination in the United States ${ }^{(3-4)}$.

It is interesting to note that, while North American nursing offered specialization, master's and doctoral courses in nursing, in the 1920s, Brazil was creating its first nursing schools in the Nightingale model. Only in 1933, 10 years after the beginning of EEAN's activities, the second nursing school in this model, Escola Carlos Chagas, was inaugurated in Belo Horizonte/Minas Gerais ${ }^{(5)}$.

From this perspective, Eliot Freidson points out that nursing requires a practice based on standardized scientific knowledge, as it encompasses much more than a craft, a doing by affinity. It involves a pattern to be followed by all professionals, a common thinking and reasoning, which can be modified if knowledge, which is flexible, changes ${ }^{(6)}$. In Brazilian nursing, Eliot Freidson's concept began with EEAN's creation.

The first nurses trained in the Anglo-American model in Brazil began their professional organization by creating a professional association (1926), which favored the exchange of knowledge between Brazilian nursing and international nursing, as the Brazilian National Association of Brazilian Graduate Nurses (Associação Nacional de Enfermeiras Diplomadas Brasileira) became a member of the International Council of Nurses in 1929, in a clear strategy of professionalization, which led to the creation of revista Annaes de Enfermagem in $1933^{(7)}$.

The entry of EEAN at Universidade do Brazil, in 1937, and the elevation of that school to an autonomous unit, in 1945, placed nursing education at a level that did not yet exist for teaching women in the country, by recognizing the autonomy of nursing in the university context. In the following decades, Brazilian nursing pursued the consolidation of its know-how as a course in the health field, socially imprinting the figure of female nurses as differentiated and necessary agents within the team ${ }^{(8)}$.

Since then, the search for scientific improvement moves the field of nursing and political advances in Brazilian education, such as the Opinion of the Federal Council of Education 21/1962, which established the first minimum curriculum for nursing, as well as the University Reform of 1968, greatly changed the professional status of nursing. Especially, this reform, in higher education, by establishing teaching-research-extension and qualification of teaching faculty by titles of master, $\mathrm{PhD}$ and professor, called university courses to graduate studies. In this context, strategies are taken by nursing leaders to create stricto sensu graduate programs in the field ${ }^{(9-10)}$.

Given the fact that graduate programs emerged in Brazil with the aim of training professionals to teach in higher education, as well as developing science and evidence-based practice, this phenomenon in Brazilian nursing began to gain strength from the 1960s onwards with the development of lato sensu specializations, consolidating itself with the approval of the first master's course in nursing at EEAN, in 1972, and the first doctoral course in nursing at Escola de Enfermagem da Universidade de São Paulo (EEUSP) in 1981

Currently, Brazilian nursing is internationally recognized due to the numerous researches carried out, the quality of its researchers, the internationalization of the profession, mostly in graduate programs. This also includes research related to the history of nursing, which are extremely important for us to know the contexts of nursing, understand how it has been built over the years and problematize the challenges that still exist, the necessary changes and other aspects that involve Brazilian and world nursing ${ }^{(5,12)}$.

However, despite the recognized relevance of research in Brazilian nursing, nurses' efforts to record the constitution of their graduate programs can be seen, generating a need for greater deepening in the problematization of institutionalization outlines and academic production in favor of constructing proper knowledge for nursing as a field of scientific knowledge, ratifying it as a profession.

\section{OBJECTIVES}

To analyze the scientific productions about the history of graduate studies in Brazilian nursing in the light of Eliot Freidson's Sociology of the Professions ${ }^{(13)}$. 


\section{METHODS}

\section{Study design}

The integrative literature review method was adopted, aiming at answering the following research question: how was the historical process of nurses' qualification in Brazil through graduate studies for the advancement of nursing as a field of knowledge itself? Integrative review is a method that allows the analysis and synthesis of results obtained in research on a particular object of study in a systematic and comprehensive way ${ }^{(14)}$.

\section{Methodological procedures}

To develop this study, five stages were followed: 1) creating the research's guiding question; 2) defining the research objectives, establishing the inclusion and exclusion criteria; 3 ) creating the search strategy used in the Virtual Health Library (VHL) portal and definition of Health Sciences Descriptors (DeCS); 4) categorizing the studies found; 5) interpreting and presenting the results ${ }^{(15)}$. For this study, the Preferred Reporting Items for Systematic Reviews and Meta-Analyses (PRISMA) recommendations were adopted ${ }^{(16)}$.

\section{Data collection and organization}

Data collection was carried out from June to September 2019, establishing a search strategy on the VHL portal, with DeCS in Brazilian Portuguese, English and Spanish being crossed using the Boolean operator AND and OR: Educação de Pós-graduação em Enfermagem, História, História da Enfermagem, Currículo, "Education, Nursing, Graduate", "Educación de Postgrado en Enfermería", "History", "Historia", "History of Nursing", "Historia de la Enfermería", "Curriculum", "Curriculum".

\section{Data analysis}

In the data collection stage, 277 manuscripts were found. After this initial search, the inclusion and exclusion criteria previously stipulated in the integrative review protocol were applied. Studies in Brazilian Portuguese, English and Spanish, scientific articles available online, published between 2008 and 2018, indexed in the VHL were included. Duplicate articles, in addition to editorials, theses and dissertations were excluded.

Regarding the different analysis techniques applied in historical studies, Thematic Content Analysis ${ }^{(17)}$ was adopted, due to the possibility of identifying nuclei of meaning in the bundles of relationships between the historicity of graduate nursing in Brazil and sociological conceptions by Eliot Freidson. Pre-analysis was started, followed by material exploration, in which units of records and categorization were evidenced, following information inference and interpretation, in the light of Eliot Freidson's approach.

For a better understanding of the search of studies that comprised the sample of this integrative review, a flowchart was built (Figure 1) with the strategy unfolding on the VHL portal and indexing databases.

Data analysis was performed in an Excel table, to facilitate the visualization of manuscripts and their data: study title, year of publication, journal, database, research design and main results. Thematic nuclei were highlighted in the light of Eliot Freidson's Sociology of the Professions: expertise/knowledge, professional status, credentials, autonomy, society, and State.

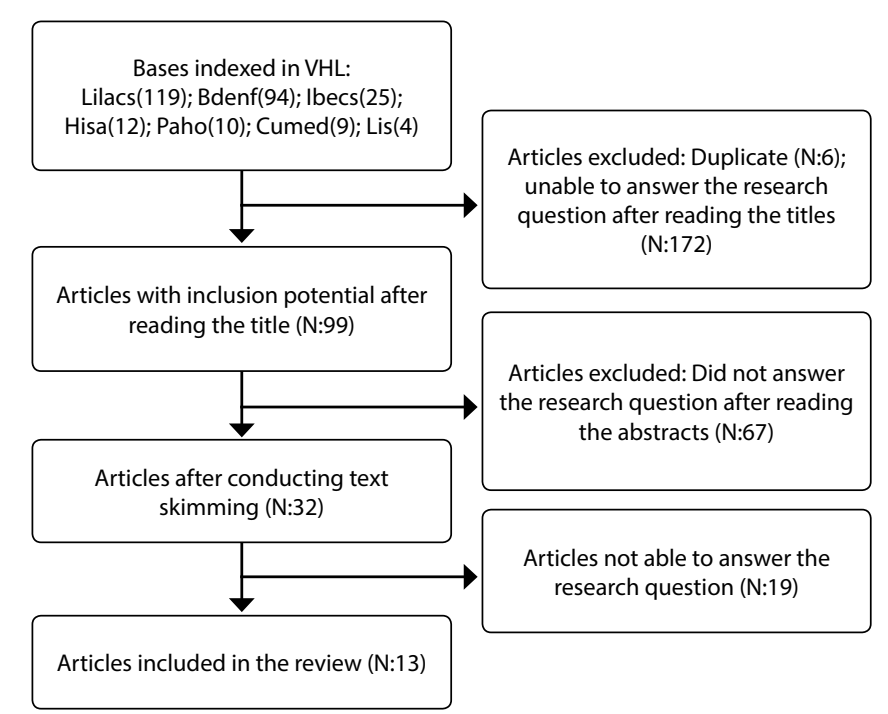

Figure 1 - Integrative review study selection process flowchart

This review consisted of 13 articles that answered the guiding question. It was observed that there were no articles with level of evidence I, 2 articles (15.38\%) of level of evidence II, 3 articles (23.08\%) of level of evidence III and 8 articles (61.54\%) of level of evidence IV, predictable since most of them are historical documentary research.

Among the selected articles, Revista Anna Nery and História da Enfermagem: Revista Eletrônica have the highest number of publications, 3 articles each (23.07\%), followed by Revista Brasileira de Enfermagem, with 2 publications (15.38\%) and the others with 1 publication (7.69\%) each: Revista Gaúcha de Enfermagem, Revista Escola de Enfermagem da Universidade do Estado do Rio de Janeiro, Revista Latino-Americana de Enfermagem, Cultura de los Cuidados, and Enfermagem em Foco.

All articles are in nursing journals and EEAN's journal is expected to stand out, given the tradition of this institution in relation to research in nursing history. Furthermore, all the articles selected for the construction of this review had a nurse as the first author.

With regard to the years of publication of articles, there is a regularity of publications ranging from 1 to 3 publications on the theme of history of graduate nursing per year.

Among the studies under analysis, it was observed that 8 articles were published in the Southeast: in São Paulo and Rio de Janeiro (61.53\%); 3 in the South, in Santa Catarina and in Rio Grande do Sul (23.07\%); 1 in the Center-West, in Brasília (7.69\%); 1 in the Northeast, in the state of Bahia (7.69\%). Such geographical distribution of production on this theme is in line with nursing schools that have made more efforts in historical nursing research.

The study of these articles allowed the researchers to analyze them considering two categories: "Institutionalization of graduate courses in Brazilian nursing", consisting of 9 articles and "The scientific production of graduate nursing in Brazil", with 4 articles. 


\section{RESULTS}

Chart 1 - Characteristics of studies in empirical category 01

Institutionalization of graduate courses in Brazilian nursing

\begin{tabular}{|c|c|c|c|}
\hline Title & Main results & $\begin{array}{l}\text { Level of } \\
\text { evidence }\end{array}$ & Journal/year/state \\
\hline $\begin{array}{l}\text { Pós-graduação em } \\
\text { enfermagem na Universidade } \\
\text { de Brasília: aspectos históricos } \\
\text { de um processo de construção } \\
\text { coletiva }^{(18)}\end{array}$ & $\begin{array}{l}\text { The stricto sensu modality grew dramatically in the period from } 1965 \text { to } \\
2005 . \text { In the Center-West Region, in 2002, Universidade Federal de Goiás was } \\
\text { the first to introduce stricto sensu graduate programs. }\end{array}$ & II & $\begin{array}{l}\text { Hist. Enferm. Rev. } \\
\text { eletrônica. } \\
2015 \\
\text { Brasília }\end{array}$ \\
\hline $\begin{array}{l}\text { Programa de Pós-Graduação } \\
\text { em Enfermagem da } \\
\text { Universidade Federal de } \\
\text { Santa Maria: trajetória e } \\
\text { resultados }^{(19)}\end{array}$ & $\begin{array}{l}\text { There is a concentration of graduate programs in southeastern Brazil, this } \\
\text { is due to the fact that the first nurses who took the course in the United } \\
\text { States were from this region. However, even today there is greater funding } \\
\text { for the Southeast Region, configuring an asymmetry of programs. }\end{array}$ & ॥ & $\begin{array}{l}\text { Rev. Gaúch. Enferm. } \\
2013 \\
\text { Rio Grande do Sul }\end{array}$ \\
\hline $\begin{array}{l}\text { Mestrado acadêmico em } \\
\text { enfermagem: interfaces de } \\
\text { sua criação na perspectiva } \\
\text { ecossistêmica }{ }^{(20)}\end{array}$ & $\begin{array}{l}\text { The graduate program in nursing at Escola de Enfermagem da Universidade } \\
\text { Federal do Rio Grande do Sul began in 2000, with a stricto sensu master's } \\
\text { course. An agreement was made with Universidade Federal de Santa } \\
\text { Catarina (UFSC) - graduate nursing network in the South; in this way, there } \\
\text { would be qualified professors to teach the course. The initial objective } \\
\text { was to train staff to form faculty capable of teaching at the higher level of } \\
\text { education. }\end{array}$ & IV & $\begin{array}{l}\text { Esc. Anna Nery Rev. } \\
\text { Enferm. } \\
2013 \\
\text { Rio Grande do Sul }\end{array}$ \\
\hline $\begin{array}{l}\text { Primeiras dissertações do } \\
\text { curso de mestrado da Escola } \\
\text { de Enfermagem Anna Nery } \\
(1972-1975)^{(21)}\end{array}$ & $\begin{array}{l}\text { The first } 9 \text { master's degrees defended at EEAN (1972-1975) adopted } \\
\text { the American teaching method based on nursing as a science and on } \\
\text { evidence-based practice. The program was created to meet the need for } \\
\text { training faculty who did not have a graduate degree. }\end{array}$ & IV & $\begin{array}{l}\text { Esc. Anna Nery Rev. } \\
\text { Enferm. } \\
2011 \\
\text { Rio de Janeiro }\end{array}$ \\
\hline $\begin{array}{l}\text { Pioneirismo da Associação } \\
\text { Brasileira de Enfermagem no } \\
\text { desenvolvimento da pesquisa: } \\
\text { da revista ao centro de } \\
\text { pesquisa }^{(22)}\end{array}$ & $\begin{array}{l}\text { After the creation of Revista Brasileira de Enfermagem (REBEn) in 1932, } \\
\text { the first vehicle for the dissemination of nurses was obtained, and the } \\
\text { congresses were the first spaces for discussion on issues related to the } \\
\text { scientific field in nursing. Creating the journal materialized an indicator } \\
\text { of work and initiatives accumulated with experiences in the field, being } \\
\text { supported in } 1971 \text { by the creation of the Center for Studies and Research } \\
\text { (CEPEn - Centro de Estudos e Pesquisas), both initiatives of ABEn (Associação } \\
\text { Brasileira de Enfermagem). }\end{array}$ & IV & $\begin{array}{l}\text { Rev. Bras. Enferm. } \\
2013 \\
\text { Rio de Janeiro }\end{array}$ \\
\hline $\begin{array}{l}\text { Escola de Enfermagem } \\
\text { da universidade de São } \\
\text { Paulo: vestígios da história } \\
\text { da profissionalização da } \\
\text { enfermagem no Brasil(23) }\end{array}$ & $\begin{array}{l}\text { In 1973, the first graduate program at EEUSP was created, with the } \\
\text { financial support of the North American institution Kellogg Foundation. } \\
\text { Due to lack of qualified professionals to teach in the programs, EEUSP } \\
\text { joined Escola de Enfermagem de Ribeirão Preto to offer a single program. } \\
\text { This union supported the growth of these schools in graduate education. }\end{array}$ & III & $\begin{array}{l}\text { Cult. Cuid. } \\
2016 \\
\text { São Paulo }\end{array}$ \\
\hline $\begin{array}{l}\text { O ensino de pós-graduação } \\
\text { em enfermagem no Brasil: } \\
\text { recorte de uma década (2001- } \\
2010)^{(24)}\end{array}$ & $\begin{array}{l}\text { Specialization courses in psychiatric nursing at Escola de Enfermagem da } \\
\text { Universidade Federal do Rio Grande do Sul and at Escola de Enfermagem de } \\
\text { Ribeirão Preto/USP were created in the 1970s, responding to the growth } \\
\text { of universities as a rational response to staff training needs specialized for } \\
\text { the labor market and the need for qualification of professionals to ascend } \\
\text { hierarchically in their careers and implement graduate studies in the field. }\end{array}$ & IV & $\begin{array}{l}\text { Hist. Enferm., Rev. } \\
\text { eletrônica. } \\
2013 \\
\text { Santa Catarina }\end{array}$ \\
\hline $\begin{array}{l}\text { Panorama da educação } \\
\text { em enfermagem no Brasil: } \\
\text { graduação e pós-graduação(25) }\end{array}$ & $\begin{array}{l}\text { The expansion of graduate courses in nursing took place after the Law } \\
\text { of Guidelines and Bases for National Education, which enabled the } \\
\text { implementation of Higher Education Institutions to meet the demands of } \\
\text { economic, political and technological development in the country. With } \\
\text { this expansionist process, a qualified faculty was required to train these } \\
\text { new nurses, instituting master's and doctoral courses in the country, with } \\
\text { most of these courses implemented in southeastern Brazil, followed by } \\
\text { northeastern and southern. }\end{array}$ & IV & $\begin{array}{l}\text { Enferm. Foco } \\
\text { (Brasília). } \\
2011 \\
\text { Bahia }\end{array}$ \\
\hline $\begin{array}{l}\text { Curso de mestrado da Escola } \\
\text { Anna Nery 1972-1975: } \\
\text { singularidades da formação e } \\
\text { desafios na implantação(26) }\end{array}$ & $\begin{array}{l}\text { In 1975, EEAN graduated the first nine masters in nursing, contributing } \\
\text { to the emergence of a new generation of nursing researchers in the } \\
\text { country. The Master's program was aimed at developing and deepening } \\
\text { undergraduate education, expand the competence levels and professional } \\
\text { skills, with an integrated approach to nursing teaching, research and care } \\
\text { delivery. }\end{array}$ & IV & $\begin{array}{l}\text { Esc. Anna Nery Rev. } \\
\text { Enferm. } \\
2015 \\
\text { Rio de Janeiro }\end{array}$ \\
\hline
\end{tabular}


Chart 2 - Publications included in empirical category 02

The scientific production of graduate nursing in Brazil

\begin{tabular}{|c|c|c|c|}
\hline Title & Main results & $\begin{array}{l}\text { Level of } \\
\text { evidence }\end{array}$ & $\begin{array}{l}\text { Journal/year/ } \\
\text { state }\end{array}$ \\
\hline $\begin{array}{l}\text { Pós-Graduação Stricto Sensu } \\
\text { em Enfermagem no Brasil: } \\
\text { avanços e perspectivas }^{(27)}\end{array}$ & $\begin{array}{l}\text { The first master's course started at EEAN (1972) had the first class formed } \\
\text { by professors from the School of Nursing of Rio de Janeiro and São } \\
\text { Paulo, with the aim of training masters from different regions so that the } \\
\text { course could be expanded to other universities. EEAN master's professors } \\
\text { specialized abroad, with the main destination in the United States. In 1976, } \\
\text { the graduate program in nursing at UFSC was created. The course had the } \\
\text { contribution of Wanda de Aguiar Horta from EEUSP. }\end{array}$ & III & $\begin{array}{l}\text { Rev. Bras. Enferm. } \\
2013 \\
\text { São Paulo }\end{array}$ \\
\hline $\begin{array}{l}\text { Políticas de saúde e } \\
\text { educação e a oferta de } \\
\text { cursos de especialização em } \\
\text { Enfermagem: } 2001-2007^{(28)}\end{array}$ & $\begin{array}{l}\text { Among the reasons that lead professionals to seek a lato sensu } \\
\text { specialization are the opportunity to enter labor market, greater } \\
\text { appreciation of professionals and increase in wage. It was observed that } \\
\text { graduate education offers followed the implementation of the main public } \\
\text { policies in the country. }\end{array}$ & IV & $\begin{array}{l}\text { Rev. Enferm. UERJ. } \\
2011 \\
\text { Rio de Janeiro }\end{array}$ \\
\hline $\begin{array}{l}\text { Produção de conhecimento } \\
\text { sobre a história da } \\
\text { enfermagem na pós- } \\
\text { graduação stricto sensu } \\
\text { brasileira }(1988-2011)^{(29)}\end{array}$ & $\begin{array}{l}\text { The production of historical studies in nursing increased from } 1990 \\
\text { onwards, and in 2000, CAPES recognized the theme as a line of research. } \\
\text { Based on a survey made about the productions, EEAN was the university } \\
\text { that produced the most titles about the history of nursing. The Southeast } \\
\text { concentrates most of productions focused on the history of nursing, being } \\
\text { considered a modest production, built with traditional analysis methods } \\
\text { and concentrated, mainly in Rio de Janeiro. }\end{array}$ & IV & $\begin{array}{l}\text { Hist. Enferm., Rev. } \\
\text { eletrônica. } \\
2014 \\
\text { São Paulo }\end{array}$ \\
\hline $\begin{array}{l}\text { Doutorado em enfermagem } \\
\text { no Brasil: formação em } \\
\text { pesquisa e produção de }_{\text {teses }^{(30)}}\end{array}$ & $\begin{array}{l}\text { Graduate programs in nursing, in the context of the Americas, began in the } \\
\text { 30s in the United States, and later expanded to Latin American countries. } \\
\text { At the doctoral level, the first courses also appear in the US, followed by } \\
\text { Brazil, Venezuela, Chile, Mexico, Argentina, Colombia and Cuba. The first } \\
\text { doctoral program in nursing in Brazil and Latin America, the University of } \\
\text { São Paulo Inter-Unit Program (Programa Interunidades da Universidade de } \\
\text { São Paulo), emerged in } 1982 \text { through the joint work of professors from } \\
\text { EEUSP, headquartered in São Paulo and Ribeirão Preto. }\end{array}$ & III & $\begin{array}{l}\text { Rev. Latino-Am. } \\
\text { Enferm. } \\
2015 \\
\text { Ribeirão Preto }\end{array}$ \\
\hline
\end{tabular}

\section{DISCUSSION}

\section{Institutionalization of graduate courses in Brazilian nursing}

Professions are the result of social constructions influenced by the historical, political and cultural context. Thus, establishing the nursing professionalization process is marked by transition from practical, empirical and non-schooled care to professional care, achieved by the search for scientific knowledge and theories that underlie this care practice ${ }^{(31)}$.

The concept of profession defended by Eliot Freidson encompasses the monopoly of knowledge in a specialized area of knowledge, autonomy, theoretical and technical criteria, expertise and credentials for qualified professional performance ${ }^{(13)}$. Thus, discussions on the historical construction of the institutionalization of graduate nursing have become essential as recognizing the unfolding of nursing development allows for a critical, reflective and constructive analysis of nursing's current context.

The articles ${ }^{(18-26)}$ that make up this category address focal and essential points in the history of graduate nursing in Brazil, highlighting the importance of specialized knowledge for professional evolution. It is highlighted that, in addition to the analysis of nursing expertise and credentialism, such productions play a role in socializing knowledge from the history of this profession that needs to be reiterated by society under state control ${ }^{(28)}$.

In this sense, the history of nursing constitutes a field of knowledge necessary for the strengthening of professional identity, makes it possible to analyze the historical-social context and provides subsidies to discuss the present and future through knowledge of the factors that influence the structural basis of contemporary society ${ }^{(5,31)}$.

The institutionalization of Brazilian graduate studies took place in a scenario of economic development, triggered during the military regime, as a strategy to generate qualified labor and provide the country's displacement into the field of research. On the other hand, professional qualification from stricto sensu graduate courses would form a national intellectual elite, necessary to establish international partnerships in the field of science and technology ${ }^{(24-26)}$.

From the perspective of Eliot Freidson's approach to professions, the State is considered an important starting point for professionalization, regulating the occupational organization of work and the construction of the teaching process, i.e., the institutions that provide the advancement and consolidation of professionalism cannot be maintained without the exercise of the State ${ }^{(13)}$. The State grants the right to professional qualification according to the historical social context experienced in the country. This is easily understood, when observing the effects of student movements in favor of advances in education during the period of military regime. As a result of the pressure established, Law 5.540/1968 was enacted, known as University Reform Law, which instituted important changes in education in the country, such as the establishment of the principle of indissolubility between teaching and research and the establishment of the requirement of stricto sensu graduate programs for the teaching career $^{(32-34)}$. 
It is worth mentioning that efforts to institutionalize graduate studies in Brazil have been taking place, since 1961, through the Law of Guidelines and Bases of Education (LDB) 4,024(32). Among the instituted innovations, the inclusion of graduate studies in Brazilian education and the requirement of complete secondary education for admission to any higher-level course stand out.

Subsequently, the organization of stricto sensu graduate education was based on the Sucupira Opinion (Opinion 977/65), approved by the then Federal Council of Education, in 1966, and by University Reform, which took place in 1968. This Opinion also instituted the system of credit units and the departments as minimum units of the university system and distinguished between lato sensu and stricto sensu graduate programs (programs in Brazil referring to specialization, master's and doctoral courses ${ }^{(33-34)}$.

The insertion of graduate studies in Brazilian nursing translated into potential to overcome the challenges that exist in a developing country that considered nursing a profession with scientific potential, when approving its academic qualification. The strategic actions adopted in graduate programs are useful for research and nursing care, providing the expansion of researchers'knowledge and inserting them in the care process committed to the advancement of nursing, in addition to contributing to nursing as a social practice ${ }^{(32-33)}$.

However, it is worth mentioning that, historically, nursing has gone through an extensive trajectory to reach the professionalization process, also reflecting in the process of consolidation of graduate nursing ${ }^{(1)}$. The professional transition process arose from the need for qualified professionals to practice nursing. It should be noted that sociologist Eliot Freidson attributes the definition of profession to a specific type of specialized work ${ }^{(35)}$.

Thus, in 1930, nursing education was regulated in Brazil and EEAN was recognized as a standard to be followed nationwide. That decade also saw the creation of Escola de Enfermagem Carlos Chagas, current Escola de Enfermagem da Universidade Federal de Minas Gerais (EEUFMG) ${ }^{(5)}$.

EEUFMG was the first school in the country to be created at the state level along the lines of "Anna Nery Standard"; in addition, EEUFMG became a leader in Minas Gerais as a pioneer in offering graduate courses ${ }^{(5)}$. This historical landmark demonstrates the consequences of professionalization of nursing in Minas Gerais and the importance of the influence of institutionalization of graduate studies in this process. The constitution of graduate studies took place in the context of higher education reform, contributing to the reconfiguration of this level of education in Brazil. Considering the occupational principle defended by Freidson, it is necessary to consider the origin of specialized knowledge in contemporary society, the way in which it is consolidated and how its development and application are assessed ${ }^{(36)}$.

Thus, in the process of institutionalization of Brazilian graduate studies, the predominant role of the Coordination for the Improvement of Higher Education Personnel (CAPES - Coordenação de Aperfeiçoamento de Pessoal de Nível Superior) stands out, responsible for promoting and assessing courses, and the Brazilian National Council Scientific and Technological Development (CNPq - Conselho Nacional de Desenvolvimento Científico e Tecnológico), responsible for encouraging the productivity of researchers ${ }^{(26,37)}$.

In the national overview of stricto sensu graduate courses in nursing, there is a predominance of programs in the Southeast ${ }^{(25-26)}$.
Asymmetry is related to the historical trajectory of nursing, as EEAN, Universidade Federal do Rio de Janeiro, is a pioneer in teaching the profession in Brazil and influenced the creation, consolidation and advancement of educational institutions in this region ${ }^{(19-20)}$.

Moreover, the country's first master's course originated at EEAN, in 1972, followed by the EEUSP graduate program's creation in $1973^{(23)}$. The emergence of graduate nursing programs in Brazil faced specific challenges, such as lack of qualified teachers to teach in stricto sensu courses, requiring the implementation of strategies to break with the non-availability of master's courses in nursing ${ }^{(21-22)}$.

Nurses linked to EEAN had the financial support of the North American institution Kellogg Foundation to carry out graduate studies in the United States, a course that has existed in that country since the $1930 \mathrm{~s}^{(33)}$. In addition to EEAN, EEUFMG and EEUSP are examples of educational institutions that have resorted to US financial support to leverage graduate programs through qualification of professors ${ }^{(5,24)}$.

Additionally, literature on graduate studies highlights the importance of North American support for creating and consolidating graduate studies in Brazilian nursing. The first master's courses in nursing, created between 1972 and 1975, adopted the North American teaching model ${ }^{(22)}$. Additionally, the Kellogg Foundation's support to create graduate programs through the offer of development grants stands out as a major factor in faculty training in different nursing schools in the country ${ }^{(21-22)}$.

Freidson highlights the importance of educational institutions in the professionalization process, but warns that knowledge can be a source of social inequality when distributed unevenly. From a nursing perspective, stratification within the same profession weakens professionalism, as can be seen in the asymmetry existing in the national overview of graduate nursing programs $s^{(27,35)}$.

The expansion of graduate studies to all regions of Brazil is a factor in democratizing access, favoring the development of research and scientific production in the country. Thus, the articulation of network work is necessary, in order to contribute to strengthening the professionalization process in nursing. Three manuscripts ${ }^{(19-21,26)}$ unveil strategies that contribute to the consolidation of graduate studies in southern Brazil; among the measures developed, the creation of Nursing Promotion Network in the South Region (REPENSUL - Rede de Promoção da Enfermagem da Região Sul) stands out, as, through networking, it enabled the emergence of new graduate nursing programs.

Brazilian graduate studies are constantly expanding, contributing to the strengthening of scientific production in nursing, in addition to the development of teaching and extension activities, which, together with research, form the tripod of universities ${ }^{(23)}$. There is a close link between graduate nursing and research that is consistent with Eliot Freidson's ideas, when presenting the importance of educational institutions in the advancement of knowledge production and in the stratification of occupations, necessary to reflect on the factors that can influence the quality of scientific production in graduate nursing programs ${ }^{(35)}$.

\section{The scientific production of graduate nursing in Brazil}

The impact of the 1968 university education reform and the institutionalization process of graduate studies made the advance of scientific research in the country viable. After this reform, there 
was a significant increase in stricto sensu graduate courses aimed at training the faculty and building a new academic profile of Brazilian scientific production ${ }^{(27-29)}$.

Therefore, historically, the emergence of nursing research in Brazil is directly related to stricto sensu graduate courses. The initial steps of scientific production took place after the entry of nursing into the Brazilian National Graduate System, which began with the first master's course in 1972, at EEAN. Strengthening the new generation of nurse researchers took place in the 1980s, with the implementation of the first doctoral course in the country ${ }^{(5,10-11)}$.

Furthermore, the lato sensu graduate program, either because of its characteristic of a target audience (care workers), or because of the historical outline of stricto sensu graduate programs, was not able to generate a significant volume of indexed production. Thus, the inclusion of scientific production linked to graduate programs is the result of Brazilian academic requirements that characterize the new university model, requiring individual efforts to produce theses, dissertations and scientific articles, aiming to obtain the required degree ${ }^{(28)}$. In this way, structuring the scientific nursing community begins and, through graduate courses, the encouragement both for the production of knowledge and for the development of skills to research ${ }^{(38-39)}$.

In this scenario, the contemporary debate on the standards of requirements that involve the productivity of researchers in stricto sensu graduate programs and the assessment criteria used stands out, aiming to guarantee quality in the process of production and dissemination of scientific knowledge ${ }^{(37,39)}$. An important aspect is the search of professionals for qualification in graduate courses, due to constant scientific advancement, as a way of entering the labor market, which, according to supply and demand, applies exclusion criteria for less qualified professionals ${ }^{(38)}$.

For Freidson, the professionalization process allows the creation of a basis for the legitimization of professional status and authority, and professional knowledge is precisely the point of differentiation between professionals, as formal knowledge can be used as a powerful tool for acquisition of power ${ }^{(13,38)}$.

The scientific production of graduate nursing courses enables the development of scientific authority, i.e., the power to enunciate the authorized discourse, in addition to improving the learning process and providing the necessary autonomy for the production of nursing knowledge ${ }^{(40-43)}$. Freidson presents the differentiation between profession and occupation through professionals' autonomy over their work, expressed by the legitimate control of their field of expertise ${ }^{(13)}$.

Thus, efforts have been made in this direction, making reference to an analysis of the profile of scientific production in nursing. Nurse researchers are more interested in addressing issues related to care practice, given the need to link and explain the scientific principles that support their practice ${ }^{(40-43)}$. Moreover, the preference for developing research focused on healthcare may be associated with the knowledge and power relations existing in the hospital field as a favorable space for the construction and reproduction of knowledge ${ }^{(42-43)}$.

Considering, on the one hand, the significant amount of research related to care practice, there is a significant growth in the number of researchers interested in the History of Nursing ${ }^{(29)}$. The legitimacy of this field of knowledge as an important and necessary area of investigation came from its recognition as a Research Line in the Brazilian National Forum of Coordinators of Graduate Nursing Courses, promoted in 2000 by CAPES ${ }^{(44)}$.

\section{Study limitations}

The study presented as a limitation the absence of articles from northern Brazil, as they are not related to the research object of this integrative review. It is supposed that the production of studies on the institutionalization of graduate studies focusing on the North Region could unveil different overviews.

\section{Contributions to nursing}

The study results contribute to understanding the institutionalization process of graduate studies and academic production in nursing as instruments for the professionalization of Brazilian nursing, resulting in evidence of nurses' identity, consolidating nursing knowledge as its own knowledge.

\section{FINAL CONSIDERATIONS}

Knowledge of profession's history allows facing the challenges of contemporary age, as it allows nurses to have a critical reflective look at the advances and obstacles faced in the profession, elucidates the influences of Brazil's social, historical and economic context, bringing answers to questions about professional identity and building solid foundations for the future of Brazilian nursing ${ }^{(27,44)}$

The publications analyzed in this study present graduate studies as a primordial space for the national construction of science. Their insertion in the country made it possible to strengthen scientific production. The qualification of nurses in Brazil, through graduate studies, contributed to the advancement of knowledge of nursing, from the acquisition and production of specialized knowledge in scientific fields, which grant nurses professional credentials.

Studying the professionalization of Brazilian nursing goes through the processes of care, research and teaching. The brief trajectory of nursing, from its implementation in the Nightingale model in the country, in 1923, until the implementation of stricto sensu graduate program, just 49 years later, leads us to reflect on how much its trajectory in the Brazilian education scenario was successful, with special relevance, in this regard, the legacy left by North American nursing, responsible for creating and implementing EEAN, which reverberated throughout the country.

\section{REFERENCES}

1. Rodrigues CC, Melo EM. Enfermagem, imagens e sentidos: uma leitura semiótica. Rev Dial Interdiscip[Internet]. 2017 [cited 2019 Sep 14];6(2):13-25. Available from: https://revistas.brazcubas.br/index.php/dialogos/article/view/286 
2. Martins DF, Benito LAO. Florence Nightingale e as suas contribuições para o controle das infecções hospitalares. Univ Ciênc Saúde. 2016;14(2):153-66. https://doi.org/10.5102/ucs.v14i2.3810

3. Silva TWM, Velloso ISC, Araújo MT, Galdino CS, Pires Jr JF, Nobre TAO. Circulação do poder-saber na constituição das práticas profissionais de médicos e enfermeiros. Rev Baiana Enferm. 2018;32:1-11. https://doi.org/10.18471/rbe.v32.28234

4. Oliveira MCM, Lima TL, Baluta VH. A Formação do profissional enfermeiro, no contexto das reformas de ensino, no Brasil. Rev Grifos[Internet]. 2014[cited 2019 Sep 14];23(36/37):161-86. Available from: https://bell.unochapeco.edu.br/revistas/index.php/grifos/article/view/2784/1766

5. Santos FBO, Carregal FAS, Rodrigues RD, Marques RC. História da enfermagem brasileira (1950-2004): o que tem sido discutido na literatura? Rev Enferm C-Oeste Min. 2018;8:e1876. https://doi.org/10.19175/recom.v7i0.1876

6. Freidson E. Profissão médica: um estudo de sociologia do conhecimento aplicado. São Paulo: Editora UNESP; 2009.

7. Teixeira KRB, Queirós PJP, Pereira LA, Peres MAA, Almeida Filho AJ, Santos TCF. Organização associativa da enfermagem: lutas pelo reconhecimento social da profissão (1943-1946). Rev Bras Enferm. 2017;70(5):1075-82. https://doi.org/10.1590/0034-7167-2017-0186

8. Aperibense PGGS, Silva CPG, Santos TCF, Almeida Filho AJ, Nelson S, Peres MAA. Uniforme de alunas de enfermagem: estratégia para construção da identidade profissional (1950-1960). Texto Contexto Enferm. 2019;28:e20170593. https://doi. org/10.1590/1980-265X-TCE-2017-0593

9. Ferreira RGS, Nascimento JL. Sustentação pedagógica e legislação do ensino aprendizagem: a formação em enfermagem no Brasil. Rev SUSTINERE. 2017;5(1):54-67. https://doi.org/10.12957/sustinere.2017.2555

10. Moreira LKR, Moreira LR, Soares MG. Educação Superior no Brasil: discussões e reflexões. Educ Escrito. Porto Alegre. 2018;9(1):134-150. https://doi.org/10.15448/2179-8435.2018.1.29594

11. Fonseca M, Fonseca DM. A gestão acadêmica da pós-graduação lato sensu: o papel do coordenador para a qualidade dos cursos. Educ Pesqui. 2016;42(1):151-164. https://doi.org/10.1590/S1517-9702201603136263

12. Gomes ATL, Salvador P, Rodrigues CCFM, Assis YMS, Bezerril MS, Santos VE. Os caminhos percorridos pela Enfermagem Brasileira na pesquisa: estudo documental. O Braz J Nurs. 2017;16(2):1-9. https://doi.org/10.17665/1676-4285.20175451

13. Freidson E. Para uma análise comparada das profissões: a institucionalização do discurso e do conhecimento formais. Rev Bras Ciênc Soc [Internet]. 1996[cited 2019 Sep 14];11(31):141-55. Available from: http://www.cff.org.br/userfiles/60\%20\%20FREIDSON\%20E\%20\%20 Para\%20uma\%20analise\%20comparada\%20das\%20profissoes_1996.pdf

14. Soares CB, Hoga LAK, Peduzzi M, Sangaleti C, Yonekura T, Silva DRAD. Revisão integrativa: conceitos e métodos utilizados na enfermagem. Rev Esc Enferm USP. 2014;48(2):335-45. https://doi.org/10.1590/S0080-623420140000200020

15. Paiva MRF, Parente JRF, Brandão IR, Queiroz AHB. Metodologias ativas de ensino aprendizagem: revisão integrativa. SANARE[Internet]. 2016[cited 2019 Sep 14];15(02):145-153. Available from: https://sanare.emnuvens.com.br/sanare/article/view/1049/595

16. Galvão TF, Pansani TSA, Harrad D. Principais itens para relatar revisões sistemáticas e meta-análises: a recomendação PRISMA. Epidemiol Serv Saúde. 2015;24(2):335-42. https://doi.org/10.5123/S1679-49742015000200017

17. Bardin L. Análise de Conteúdo. São Paulo: Edições 70, 2016.

18. Alves ED, Rodrigues MCS, Silva O. Pós-graduação em enfermagem na Universidade de Brasília: aspectos históricos de um processo de construção coletiva. Hist Enferm Rev Eletrônica [Internet]. 2015[cited 2019 Sep 14];6(1):147-62. Available from: http://here.abennacional. org.br/here/10_RX_24014_MM.pdf.

19. Linch GFC, Ribeiro AC, Guido LA. Programa de Pós-Graduação em Enfermagem da Universidade Federal de Santa Maria: trajetória e resultados. Rev Gaúcha Enferm[Internet]. 2013[cited 2019 Sep 14];34(1):147-54. Available from: https://seer.ufrgs.br/RevistaGauchadeEnfermagem/article/view/28446

20. Oliveira NA, Siqueira HCH. Mestrado acadêmico em enfermagem: interfaces de sua criação na perspectiva ecossistêmica. Esc Anna Nery. 2013;17(1):73-81. https://doi.org/10.1590/S1414-81452013000100011

21. Machado CA, Barreira IA, Martins ALT. Primeiras dissertações do curso de mestrado da Escola de Enfermagem Anna Nery. Esc Anna Nery [Internet]. 2011 [cited 2019 Sep 14];15(2):331-8. Available from: http://www.scielo.br/pdf/ean/v15n2/v15n2a16.pdf

22. Pereira LA, Santos TCF. Pioneirismo da associação brasileira de enfermagem no desenvolvimento da pesquisa: da revista ao centro de pesquisa. Esc Anna Nery. 2013;17(3):526-33. https://doi.org/10.1590/S1414-81452013000300017

23. Freitas GF, Bonini BB, Silva EC, Araújo TA, Mattozinho FCB. Escola de Enfermagem da Universidade de São Paulo: vestígios da história de profissionalização em Enfermagem no Brasil. Cult Cuid. 2016;20(46). https://doi.org/10.14198/cuid.2016.46.07

24. Carlos DJD, Morera JAC, Lazzari DD, Padilha MICS. O ensino de pós-graduação em enfermagem no brasil: recorte de uma década (20012010). Hist Enferm Rev Eletrônica[Internet]. 2013[cited 2019 Sep 14];140-52. Available from: http://www.here.abennacional.org.br/here/ vol4num2artigo4.pdf

25. Erdmann AL, Fernandes JD, Teixeira GA. Panorama da educação em enfermagem no Brasil: graduação e pós-graduação. Enferm Foco[Internet]. 2011 [cited 2019 Sep 14];2(supl):89-93. Available from: http://revista.cofen.gov.br/index.php/enfermagem/article/view/91/76

26. Mendes ALTM, Aperibense PGGS, Almeida Filho AJ, Peres MAA. Curso de mestrado da Escola Anna Nery 1972-1975: singularidades da formação e desafios na implantação. Esc Anna Nery. 2015;19(1):11-17. https://doi.org/10.5935/1414-8145.20150002

27. Padilha MICS, Borenstein Scochi CGS, Munari DB, Gelbcke FL, Erdmann AL, Gutiérrez MGR, et al. Pós-Graduação Stricto Sensu em Enfermagem no Brasil: avanços e perspectivas. Rev Bras Enferm. 2013;66(esp):80-9. https://doi.org/10.1590/S0034-71672013000700011 
28. Barbosa TSC, Almeida Filho AJ, Santos TCF, Gomes MLB, Oliveira AB, Souza MCF. Políticas de saúde e educação e a oferta de cursos de especialização em Enfermagem: 2001-2007. Rev Enferm UERJ[Internet]. 2011[cited 2019 Sep 14];19(2):292-8. Available from: http://www. facenf.uerj.br/v19n2/v19n2a20.pdf

29. Meneses AS, Sanna MC. Produção do conhecimento sobre história da enfermagem na pós-graduação stricto sensu brasileira (19882011). Hist Enferm Rev Eletrônica [Internet]. 2014[cited 2019 Sep 14];5(2):146-68. Available from: http://www.abennacional.org.br/ centrodememoria/here/vol5num2artigo11.pdf

30. Scochi CGS, Gelbcke FL, Ferreira MA, Lima MADS, Padilha KG, Padovani NA, et al. Doutorado em enfermagem no Brasil: formação em pesquisa e produção de teses. Rev Latino-Am Enfermagem. 2015;23(3):387-94. https://doi.org/10.1590/0104-1169.0590.2564

31. Pimenta AL, Souza ML. Identidade profissional da enfermagem nos textos publicados na REBEn. Texto Contexto Enferm. 2017;26(1):e4370015. https://doi.org/10.1590/0104-07072016004370015

32. Presidência da República (BR). Lei 4.024, de 20 de dezembro de 1961. Fixa as Diretrizes e Bases da Educação Nacional [Internet]. Brasília: DF. 1961 [cited 2019 Sep 14]. Available from: https://www2.camara.leg.br/legin/fed/lei/1960-1969/lei-4024-20-dezembro-1961-353722publicacaooriginal-1-pl.html

33. Ministério da Educação (BR). Parecer no 977/65. Aprovado em 3 de dezembro de 1965. Brasília: MEC/CEF; 1965. https://doi.org/10.1590/ S1413-24782005000300014

34. Presidência da República (BR). Reforma universitária: relatório do grupo de trabalho criado pelo decreto n. 62937/68 [Internet]. Brasília: Presidência da República, 1968[cited 2019 Sep 14]. Available from: https://www2.camara.leg.br/legin/fed/decret/1960-1969/decreto-629372-julho-1968-404810-publicacaooriginal-1-pe.html

35. Freidson E. Renascimento do Profissionalismo: teoria, profecia e política. São Paulo: Edusp; 1998. https://doi.org/10.1590/ S0102-69091999000100013

36. Bellaguarda MLR, Padilha MI, Nelson S. Eliot Freidson's sociology of professions: an interpretation for Health and Nursing. Rev Bras Enferm. 2020;73(6):e20180950. https://doi.org/10.1590/0034-7167-2018-0950

37. Kisil M. A fundação W.K. Kellogg e o desenvolvimento da enfermagem na América Latina. Rev Latino-Am Enfermagem[Internet]. 1993[cited 2019 Sep 14];1(1):37-42. Available from: http://www.revistas.usp.br/rlae/article/view/1089/1103

38. Mendonça GMMM, Cestari VRF, Rodrigues LN, Sampaio MOM, Freitas MC, Guedes MVC. Produção científica de egressos de um programa de pós-graduação em enfermagem. Rev Pesqui: Cuid Fundam. 2018;10(2):485-489. https://doi.org/10.9789/2175-5361.2018.v10i2.485-489

39. Rodrigues RAP, Robazzi MLCC, Erdmann AL, Fernandes JD, Barros ALBL, Ramos FRS. Teses de Doutorado dos Programas de Pós-graduação em Enfermagem do Brasil e sua Associação com os Objetivos de Desenvolvimento do Milênio. Rev Latino-Am Enfermagem. 2015;23(3):395403. https://doi.org/10.1590/0104-1169.0667.2565

40. Baptista MKS, Santos RM, Duarte SJH, Comassetto I, Trezza MCSF. O paciente e as relações de poder-saber cuidar dos profissionais de enfermagem. Esc Anna Nery. 2017;21(4). https://doi.org/10.1590/2177-9465-EAN-2017-0064

41. Bellaguarda MLR, Padilha MI, Peres MAA, Paim L. Enfermagem profissão: seu status, eis a questão. Rev. Enferm. UERJ. Rio de Janeiro, 2016;24(2):e8591. https://doi.org/10.12957/reuerj.2016.8591

42. Silva SED, Santos ALS, Dias BJC, Furtado IP, Ribeiro ISO, Seidel MA, et al. Associação Brasileira de Enfermagem: as representações sociais dentro das pesquisas em enfermagem no contexto atual. J Health Biol Sci. 2019;6(3):342-6. https://doi.org/10.12662/2317-3076jhbs. v6i3.1754.p342-346.2018

43. Meneses AS, Sanna MC. Produção do conhecimento sobre história da enfermagem na pós-graduação stricto sensu brasileira (19882011). Hist Enferm Rev Eletrônica [Internet]. 2014[cited 2019 Sep 14];5(2):146-68. Available from: http://www.abennacional.org.br/ centrodememoria/here/vol5num2artigo11.pdf

44. Padilha MICS, Kletemberg DF, Gregório VRP, Borges LM, Borenstein MS. A produção da pesquisa histórica vinculada aos programas de PósGraduação no Brasil, 1972 a 2004. Texto Contexto Enferm[Internet]. 2007[cited 2019 Sep 14];16(4):671-9. Available from: http://www.scielo. $\mathrm{br} / \mathrm{pdf} / \mathrm{tce} / \mathrm{v} 16 \mathrm{n} 4 / \mathrm{a} 11 \mathrm{v} 16 \mathrm{n} 4 . \mathrm{pdf}$ 